\title{
PENGGUNAAN PESTISIDA NABATI MENGENDALIKAN HAMA- HAMA PADI MERAH (Oryza nivara L.) DI DUSUN SOPORARU, TAPANULI UTARA, SUMATERA UTARA
}

\author{
Ameilia Zuliyanti Siregar ${ }^{1^{*}}$, Tulus $^{2}$, dan Kemala Sari Lubis ${ }^{3}$ \\ ${ }^{1,3}$ Fakultas Pertanian Universitas Sumatera Utara, Jl. Dr.A.Soyan No 3 Medan 20155 \\ Sumatera Utara \\ ${ }^{2}$ Fakultas Matematika \& Ilmu Pengetahuan Alam, Universitas Sumatera Utara, Jl. \\ Bioteknologi Medan \\ E-Mail: *ameiliazuliyanti@gmail.com
}

\begin{abstract}
ABSTRAK
Penggunaan Pestisida Nabati Mengendalikan Hama-Hama Padi Merah (Oryza nivara L.) DI Dusun Soporaru, Tapanuli Utara, Sumatera Utara.

Beras merah spesifik lokal Natabo diidentifikasi di Kecamatan Pangaribuan, Tapanuli Utara, dimana serangan empat jenis hama dominan dari penggerek batang, wereng batang coklat, wereng daun, walang sangit mempengaruhi produktivitas padi. Salah satu cara mengendalikan hama secara hayati dilakukan dengan penggunaan pestisida nabati untuk meningkatkan produktivitas dan ketahanan pangan. Penelitian ini dilaksanakan selama delapan bulan, Maret sampai Oktober 2020, dengan tahapan survei, inventarisasi hama dilapangan menggunakan metode purpossive random sampling di Dusun Soporaru, Desa Sigotom Julu, Kecamatan Pangaribuan, Tapanuli Utara. Aplikasi pestisida nabati terdiri dari 5 perlakuan, yaitu: B0 (Kontrol, tanpa aplikasi); BP1 (daun nimba, lengkuas, serai, deterjen, air); BP2 (daun sirsak, rimpang jeringau, bawang putih, deterjen, air); BP3 (daun sirsak, deterjen, air) dan BP4 (daun kenikir, bunga marigold, daun-bunga kertas). Komposisi serangga diperoleh 8 ordo, 26 famili dengan total sebanyak 1.080 ekor.Perhitungan indeks kekayaan jenis $(\mathrm{R})$ Margalef $(\mathrm{Rp}=7.25$; $\mathrm{Rk}=7.15)$,indeks kemerataan Evenness $(\mathrm{Ep}=0.62 ; \mathrm{Ek}=0.57)$ serta indeks keanekaragaman Shannon Wiener $(\mathrm{Hp}=2.38 ; \mathrm{Hk}=2.12)$.Parameter suhu, kelembaban, curah hujan dihitung.Penggunaan pestisida nabati berpotensi strategis dalam mengendalikan hama dominan padi di masa depan.
\end{abstract}

Kata kunci : Pestisida nabati, mengendalikan, hama, padi merah, Tapanuli Utara.

\begin{abstract}
The Use of Biopestisides to Control of Red Rice Pests (Oryza nivara L.) in Soporaru sub-village, North Tapanuli, North Sumatra.

Locally specific Natabo brown rice was identified in Pangaribuan Subdistrict, North Tapanuli, where the attack of dominance pests, such as: stem borer, brown planthoppers, leafhoppers and stink bugs affects rice productivity. The alternative step to control pests in a biologically is by using biology pesticides to increase productivity and food security. This research was conducted for eight months during March to October 2020, with a survey stage, inventory of pests in the fields using the purposive random sampling method in Soporaru sub village, Sigotom Julu Village, Pangaribuan District, North Tapanuli. The application of biology pesticides consists of 5 treatments, namely: BO (Control, without application); BP1 (neem leaves, galangal, lemongrass, detergent, water); BP2 (soursop leaves, galangal rhizome, garlic, detergent, water); BP3 (soursop leaves, detergent, water) and BP4 (kenikir leaves, marigold flowers, Zinnia flowers). The composition of insects consist of 8 order, 26 familes, totalpopulation were 1.080 individuals.The calculation of the Margallef species richness index $(R p=7.25 ; R c=7.15)$, the Evenness evenness index $(E p=0.62$; $E c=0.57)$ and the Shannon Wiener diversity index $\left(H p^{\prime}=2.38 ; H c^{\prime}=2.12\right)$. The parameters of temperature, humidity, rainfall) are calculated. The use of biology pesticides has strategic potential in controlling the dominant pests of rice in the future.
\end{abstract}

Key words : Biopesticides, controlling, pests, red rice, North Tapanuli. 


\section{PENDAHULUAN}

Tanaman padi (Oryza sativa L.) merupakan tanaman penghasil beras sebagai sumber karbohidrat bagi penduduk dunia. Di Indonesia, sebanyak lebih dari 97\% mengonsumsi beras sebagai bahan bahan makanan, sehingga permintaan kebutuhan beras setiap tahunnya meningkat, didukung oleh bertambahnyatingkat kelahiran di negara kita Menurut data Badan Pusat Statistik (2020), konsumsi beras di Indonesia tergolong tinggi (31.31 juta ton GKG) tercatat pada tahun 2019 .

Manakala, produktivitas padi menurun, salah satu faktor penyebabnya adalah serangan hama dan penyakit pada tanaman padi. Pada areal pertanaman padi di Indonesia teridentifikasi beberapa hama-hama dominan, diantaranya adalah lalat bibit, orong-orong, ulat jengkalpalsu hijau, ulat tanduk hijau, ulat tentara/grayak, hama putih, hama putih palsu, ganjur, kepinding tanah, wereng hijau, wereng coklat, penggerek batang dan walang sangit (Siregar, 2018; Sodiq dan Mujoko, 2020).

Disamping itu, petani seringkali menggunakan bahan kimia sebagai langkah awal membasmi hama dan penyakit pada lahan pertanaman padi. Tetapi dampak dari penggunaan bahan kimia tersebut baru muncul yang mengakibatkan peledakan Organisme Pengganggu Tanaman (OPT) di lahan pertanaman padi. Menurut Wiyono dkk (2014), hama padi akan meningkat populasinya jika penggunaan pestisida tidak sesuai anjuran. Oleh karena itu perlu dilakukan Prinsip Pengendalian Hama Terpadu (PHT) dengan cara pemanfaatan musuh alami, budidaya tanaman sehat, dan pengamatan berkala oleh petani serta ahli PHT dilapangan.

Disamping itu, aktivitas PHT sederhana dapat dilakukan petani menggunakan pestisida nabati atau dikenal dengan nama pesnab. Pestisida nabati terbagi atas 2 jenis, yaitu satu jenis bahan aktif (single active ingredient) atau beberapa jenis bahan aktif (multiple active ingredient) (Kardinan 1999). Hasil penelitian menunjukkan bahwa beberapa jenis pestisida nabati cukup efektif terhadap beberapa jenis hama, baik hama di lapangan, seperti lalat buah, nyamuk, kumbang (Kardinan 2004; 2005; 2006).

Beberapa jenis pestisida nabati, seperti: daun mimba, selasih (Kardinan 2004; 2007; Siregar dkk, 2019), lengkuas (Heny dan Turang, 2011), bawang putih (Amiranti, 2005; Rusdy, 2010), daun sirsak, serai (Putra dan Zein, 2016) mengontrol hama keong mas di padi. Manakala daun bunga marigold (Tagetes erecta) (Muhibah dan Leksono, 2015), daun bunga kertas (Zinnia elegans), daun bunga kenikir (Cosmos caudatus) (Aldini, dkk, 2019; Betharia, dkk., 2018) diprediksikan dapat mengendalikan hama tanaman padi merah. Insektisida nabati dapat berfungsi sebagai penolak, penarik, antifertilitas, dan membunuh serangga lain (Listiyati dkk, 2012).

Secara geografis tercatat Kabupaten Tapanuli Utara terletak pada koordinat $1^{\circ} 20^{\prime} 00^{\prime}$ " hingga $2^{\circ} 41^{\prime} 00^{\prime \prime}$ Lintang Utara (LU) dan 98 $05^{\prime}-99^{\circ} 16^{\prime}$ ' Bujur Timur (BT). Dengan luas wilayah yang dimiliki $\pm 3.800,31 \mathrm{~km}^{2}$, luas panen sebesar 22 384,9 ha, produksi sebanyak 108639,1 ton, manakala rata-rata produksi sebesar 48,53 kw/ha (BPS, 2019). Kebutuhan akan komoditi padi penghasil beras memegang peranan penting bagi kehidupan bangsa Indonesia pada umumnya dan bagi masyarakat Kabupaten Tapanuli Utara pada khususnya. Terdapat beberapa permasalahan yang teridentifikasi di Desa Soporaru, diantaranya adalah:

1. Rendahnya pengetahuan petani dalam menginventarisasi hama-hama dominan padi.

Terbatasnya pengetahuan dan pemahaman petani dalam memanfaatkan 
pengendalian hama terpadu ramah lingkungan pada pertanaman padi.

Oleh karena itu diperlukan penelitian untuk mengendalikan hama dan penyakit tanaman padi secara hayati menggunakan pestisida nabati untuk mengetahui komposisi, perbandingan kekayaan jenis, keanekaragaman, keseragaman serangga pada pertanaman padi. Selanjutnya diprediksi akan dapat diambil tindakan tepat dalam mengendalikan ham-hama dominan seperti Leptocorisa oratorius dan Sogatella sp pada pertanaman padi di Dusun Soporaru, Tapanuli Utara.

\section{METODA PENELITIAN}

\subsection{Tempat dan Waktu}

Penelitian ini dilaksanakan pada lahan petani padi (800 meter $\left.{ }^{2}\right)$ di Dusun Soporaru, Desa Sigotom Julu, Kecamatan Pangaribuan, Kabupaten Tapanuli Utara, Sumatera Utara selama bulan Maret-Oktober 2020.

\subsection{Bahan dan Alat}

Adapun bahan yang dibutuhkan dalam penelitian ini adalah daun nimba (Azadirachta indica), rimpang lengkuas (Alpinia galanga), batang serai (Cymbopogon citratus), daun sirsak (Annona muricata), bawang putih (Allium sativum), daun bunga kenikir (Cosmos caudatus), daun bunga marigold (Tagetes erecta), daun bunga kertas (Zinnia elegans), air, dan sabun deterjen.

Adapun alat yang digunakan dalam penelitian ini adalah, handsprayer drum, pisau, saringan, blender, spatula, pinset, mikroskop, dan alat pendukung lainnya.

\subsection{Tahapan Penelitian}

Penelitian ini terdiri dari tahapan survei, penelitian dilapangan, identifikasi hama di laboratorium, aplikasi pestisida nabati dan analisis data. Metode yang digunakan adalah purposive sampling pada empat petakan (BP1, BP2, BP3, BP4) dengan cara pembuatan pestisida nabati sebagai berikut:

1. Pestisida Nabati 1 (BP1), terdiri dari: daun nimba $(8 \mathrm{~kg})$, lengkuas $(6 \mathrm{~kg})$, serai $(6 \mathrm{~kg})$, deterjen (20gr), dan air (20L). Cara membuat pestisida nabati 1 dengan menyediakan bahan sesuai ukuran, kemudian daun nimba, lengkuas, dan serai di tumbuk atau dihaluskan. Seluruh bahan diaduk merata dalam $20 \mathrm{~L}$ air lalu direndam sehari semalam (24 jam). Keesokan harinya ekstrak disaring menggunakan kain halus. Larutan hasil penyaringan diencerkan kembali dengan $30 \mathrm{~L}$ air. Larutan sebanyak itu dapat digunakan untuk lahan seluas 1 ha.Larutan pestisida nabati ini siap digunakan untuk mengendalikan hama walang sangit (Leptocorisa oratorius).

2. Pestisida Nabati 2 (BP2), terdiri daun sirsak (500gr), lengkuas (500gr), bawang putih (250gr), deterjen (20gr), dan air (20L). Cara membuat pestisida nabati 2 dengan menyediakan bahan sesuai ukuran lalu daun sirsak, lengkuas, dan bawang putih ditumbuk atau dihaluskan. Seluruh bahan dicampur dengan deterjen kemudian direndam dalam $20 \mathrm{~L}$ air selama 1 hari. Keesokan harinya larutan bahan disaring dengan kain halus. Setiap $1 \mathrm{~L}$ hasil saringan dapat diencerkan dengan 10-15L air. Larutan sebanyak itu dapat digunakan untuk lahan seluas 1 ha. Larutan pestisida nabati ini siap digunakan untuk mengendalikan hama wereng coklat (Nilaparvata lugens).

3. Pestisida Nabati 3 (BP3), terdiri dari daun sirsak (500 gr), deterjen (20 gr), dan air (20L). Cara membuat pestisida nabati 3 dengan menyediakan bahan 
sesuai ukuran. Selanjutnya seluruh bahan ditumbuk dan dihaluskan lalu seluruh bahan dicampur dengan deterjen, kemudian direndam dalam 20 L selama sehari (24 jam). Keesokan harinya ekstrak disaring menggunakan kain halus. Larutan hasil penyaringan diencerkan kembali dengan 20L air. Larutan sebanyak itu dapat digunakan untuk lahan seluas 1 ha. Larutan pestisida nabati ini siap digunakan untuk mengendalikan hama Nephotettix sp.

4. Pestisida Nabati 4 (BP4), terdiri dari daun bunga kenikir (500gr), daun bunga marigold (500gr), daun bunga kertas (500gr), deterjen (20 gr), dan air (20L). Cara membuat pestisida nabati 4 dengan menyediakan bahan sesuai ukuran. Selanjutnya seluruh bahan ditumbuk dan dihaluskan lalu seluruh bahan dicampur dengan deterjen, kemudian direndam dalam $20 \mathrm{~L}$ selama sehari (24 jam). Keesokan harinya ekstrak disaring menggunakan kain halus. Larutan hasil penyaringan diencerkan kembali dengan 20L air.Larutan sebanyak itu dapat digunakan untuk lahan seluas 1 ha.Larutan pestisida nabati ini siap digunakan untuk mengendalikan hama S.inonata. Penggunaan pestisida nabati

$$
\mathrm{R} 1=\frac{\mathrm{S} 1}{\mathrm{In}}
$$

$\mathrm{R}=$ Indeks kekayaan jenis

$\mathrm{S}=$ Jumlah total jenis

$\mathrm{N}=$ Total individu (Ludwig dan Reynold, 1988). ini diharapakan dapat mengendalikan beberapa hama-hama dominan padi merah, seperti: L.oratorius, $N$. lugens, Nephotettix sp dan S. inonata.

\subsection{Teknik Pengumpulan Data}

Dari lima petakan sawah padi di ambil masing masing tiga sampel rumpun padi. Pada tiap sampel. Aplikasi pestisida nabati dilaksanakan selama 4 kali selama dengan interval pengambilan sampel berkisar 7 hari. Serangga yang tertangkap dikumpulkan, diidentifikasi menggunakan buku Heinrichs (1995), Shepard et al. (2011), dan IRRI (1994). Parameter pengamatan (kekayaan, kelimpahan, keseragaman, keanekaragaman serangga, serta faktor suhu, kelembaban, curah hujan) dihitung.

\subsection{Peubah Amatan dan Analisis Data}

Dilakukan perhitungan Kerapatan Mutlak (KM); Kerapatan Relatif (KR); Frekuensi Mutlak (FM); Frekuensi Relatif (FR), R1, dan H'dengan rumusan berikut ini:

a. Indeks Kekayaan Jenis Margalef (R) Indek Margalef menggunakan formula: 
b. Eveness

$$
\mathrm{E}=\frac{\mathrm{Ni}}{\mathrm{S}}
$$

$\mathrm{Ni}=$ Jumlah Jenis dengan kelimpahan sama

$\mathrm{S}=$ Jumlah individu dalam satu unit contoh

\section{c. Indeks Keanekaragaman Suatu Jenis Serangga (H')}

Formula indeks keseragaman berikut:

Formula indeks Shannon Wiener sebagaiberikut:

$$
\begin{aligned}
& \mathbf{H}^{s}=\sum_{\mathbf{i}=1}^{5}(\mathbf{p i})(\operatorname{In} \mathbf{p i}) \\
& \mathbf{p i}=\mathbf{p i} / \mathbf{N}
\end{aligned}
$$

$\mathrm{pi}=$ Proporsi jumlah individu ke-i dengan jumlah total individu

$\mathrm{ni}=$ jumlah individu jenis $\mathrm{ke}-\mathrm{i}$

$\mathrm{N}=$ jumlah total semua individu dalam sampel

$\ln =$ logaritma ke basis e

Dengan kriteria indeks keanekaragaman menurut Krebs (1978) sebagai berikut:

$\mathrm{H}>3$ = Tinggi; $1<\mathrm{H}<3$ = Sedang; $\mathrm{H}<1=$ Rendah

\section{HASIL PENELITIAN DAN PEMBAHASAN}

Dari hasil penelitian dilapangan sebanyak 4 kali pengambilan sampel pada lahan padi dengan Pestisida nabati diidentifikasi jumlah dan jenis serangga yang tertangkap pada areal pertanaman padi merah Natabo di Soporaru terdiri dari 8 ordo, 26 famili dengan total sebanyak 1.080 ekor dapat di lihat pada Tabel 1 berikut ini. 
Tabel 1. Komposisi serangga di lahan padi merah dengan penggunaan pestisida nabati

\begin{tabular}{|c|c|c|c|c|c|c|c|c|c|c|c|c|c|c|c|c|c|c|}
\hline Order & Families & $\begin{array}{l}\text { Genera } \\
\end{array}$ & $\begin{array}{l}\text { IPN } \\
1\end{array}$ & $\begin{array}{l}1 \mathrm{PN} \\
2\end{array}$ & $\begin{array}{l}\mathrm{P} \\
\mathrm{N} 3\end{array}$ & $\begin{array}{l}1 \mathrm{PN} \\
4\end{array}$ & $\begin{array}{l}2 \mathrm{PN} \\
1\end{array}$ & $\begin{array}{l}2 \mathrm{PN} \\
2\end{array}$ & $\begin{array}{l}2 \mathrm{PN} \\
3\end{array}$ & $\begin{array}{l}2 \mathrm{PN} \\
4\end{array}$ & $\begin{array}{l}3 \mathrm{PN} \\
1\end{array}$ & $\begin{array}{l}3 \mathrm{PN} \\
2\end{array}$ & $\begin{array}{l}3 \mathrm{PNN} \\
3\end{array}$ & $\begin{array}{l}3 \mathrm{P} \\
\mathrm{N} 4\end{array}$ & $\begin{array}{l}4 \mathrm{PN} \\
1\end{array}$ & $\begin{array}{l}4 \mathrm{P} \\
\mathrm{N} 2\end{array}$ & $\begin{array}{l}\mathrm{PP} \\
\mathrm{N} 3\end{array}$ & $\begin{array}{l}4 \mathrm{PNN} \\
4\end{array}$ \\
\hline Coleoptera & Coccinellidae & $\begin{array}{l}\text { C.septe } \\
\text { mpunct } \\
\text { ata }\end{array}$ & ++ & ++ & + & + & ++ & ++ & + & + & ++ & ++ & ++ & ++ & ++ & ++ & +++ & ++ \\
\hline Coleoptera & Hydrophilidae & $\begin{array}{l}\text { Hydrob } \\
\text { ius sp }\end{array}$ & + & + & + & + & ++ & ++ & + & + & ++ & ++ & + & + & ++ & ++ & ++ & ++ \\
\hline Coleoptera & Chrysomelidae & $\begin{array}{l}\text { Leptisp } \\
\text { a sp }\end{array}$ & + & + & + & + & + & + & + & + & + & + & + & + & ++ & ++ & + & + \\
\hline Coleoptera & Staphylidae & $\begin{array}{l}\text { Paeder } \\
\text { us sp }\end{array}$ & + & + & + & + & ++ & ++ & + & + & ++ & ++ & ++ & ++ & ++ & ++ & ++ & ++ \\
\hline Diptera & Anisopodidae & $\begin{array}{l}\text { Anisop } \\
s p\end{array}$ & + & + & + & + & + & + & + & + & + & + & + & + & + & + & + & + \\
\hline Diptera & Cecidomylidae & $\begin{array}{l}\text { Orseoli } \\
\text { a } \\
\text { oryzae } \\
\end{array}$ & ++ & ++ & ++ & ++ & ++ & ++ & ++ & ++ & ++ & ++ & ++ & ++ & ++ & ++ & ++ & ++ \\
\hline Diptera & Calliphoridae & $\begin{array}{l}\text { Lucia } \\
\text { sericata }\end{array}$ & + & + & + & + & + & + & + & + & + & + & + & + & + & + & + & + \\
\hline Diptera & Culicidae & $\begin{array}{l}\text { Anophe } \\
\text { les sp }\end{array}$ & ++ & ++ & ++ & ++ & ++ & ++ & ++ & ++ & ++ & ++ & ++ & ++ & +++ & +++ & ++ & ++ \\
\hline Diptera & Culicidae & $\begin{array}{l}\text { Culex } \\
s p\end{array}$ & ++ & ++ & ++ & ++ & ++ & ++ & ++ & ++ & +++ & +++ & ++ & ++ & +++ & +++ & ++ & ++ \\
\hline Diptera & Ephydridae & $\begin{array}{l}\text { Hydrell } \\
\text { ia sp }\end{array}$ & ++ & ++ & +++ & ++ & ++ & ++ & ++ & ++ & ++ & ++ & ++ & ++ & ++ & ++ & ++ & ++ \\
\hline Diptera & Muscidae & $\begin{array}{l}\text { Atherig } \\
\text { on } s p\end{array}$ & ++ & ++ & ++ & ++ & ++ & ++ & ++ & ++ & ++ & ++ & ++ & ++ & ++ & ++ & ++ & ++ \\
\hline Diptera & Tabanidae & $\begin{array}{l}\text { Tabanu } \\
\text { ssp } \\
\end{array}$ & + & + & + & + & + & + & + & + & + & + & + & + & + & + & + & + \\
\hline Hemiptera & Alydidae & $\begin{array}{l}\text { Lorota } \\
\text { rius } s p\end{array}$ & ++ & ++ & ++ & ++ & +++ & +++ & ++ & +++ & +++ & +++ & ++ & $\begin{array}{l}++ \\
+\end{array}$ & +++ & +++ & ++ & +++ \\
\hline Hemiptera & Chrysomelidae & $\begin{array}{l}\text { Nephot } \\
\text { ettix sp }\end{array}$ & ++ & ++ & ++ & ++ & ++ & ++ & ++ & ++ & ++ & ++ & ++ & ++ & ++ & ++ & ++ & ++ \\
\hline Hemiptera & Delphacidae & $\begin{array}{l}\text { N.lugen } \\
s\end{array}$ & +++ & ++ & +++ & ++ & ++++ & ++++ & $\begin{array}{ll}++ \\
\end{array}$ & +++ & +++ & +++ & $\begin{array}{ll}++ \\
++\end{array}$ & $\begin{array}{c}++ \\
+\end{array}$ & ++++ & ++++ & +++ & +++ \\
\hline Hemiptera & Pentatomidae & $\begin{array}{l}\text { Scatino } \\
\text { phora } \\
s p \\
\end{array}$ & ++ & ++ & ++ & ++ & ++ & ++ & ++ & ++ & ++ & ++ & ++ & ++ & ++ & ++ & +++ & ++ \\
\hline $\begin{array}{l}\text { Hymenopte } \\
\text { ra }\end{array}$ & Apidae & $\begin{array}{l}\text { Aphis } \\
\text { sp }\end{array}$ & + & + & + & + & + & + & + & + & + & + & + & + & + & + & + & + \\
\hline $\begin{array}{l}\text { Hymenopte } \\
\text { ra }\end{array}$ & Formicidae & $\begin{array}{l}\text { Compo } \\
\text { notus } \\
s p\end{array}$ & + & + & + & + & + & + & + & + & + & + & + & + & + & + & + & + \\
\hline $\begin{array}{l}\text { Hymenopte } \\
\text { ra }\end{array}$ & Formicidae & $\begin{array}{l}\text { Fomoca } \\
\text { rfatus } \\
s p \\
\end{array}$ & ++ & ++ & ++ & ++ & ++ & ++ & ++ & ++ & ++ & ++ & ++ & ++ & ++ & ++ & ++ & ++ \\
\hline $\begin{array}{l}\text { Order } \\
\end{array}$ & Families & $\begin{array}{l}\text { Genera } \\
\end{array}$ & $\begin{array}{l}\text { IPN } \\
1\end{array}$ & $\begin{array}{l}1 \mathrm{PN} \\
2\end{array}$ & $\begin{array}{l}\mathrm{P} \\
\mathrm{N} 3\end{array}$ & $\begin{array}{l}1 \mathrm{PN} \\
4\end{array}$ & $\begin{array}{l}2 \mathrm{PN} \\
1\end{array}$ & $\begin{array}{l}2 \mathrm{PNN} \\
2\end{array}$ & $\begin{array}{l}2 \mathrm{PN} \\
3\end{array}$ & $\begin{array}{l}2 \mathrm{PNN} \\
4\end{array}$ & $\begin{array}{l}3 \mathrm{PN} \\
1\end{array}$ & $\begin{array}{l}3 \mathrm{PN} \\
2\end{array}$ & $\begin{array}{l}3 \mathrm{PNN} \\
3\end{array}$ & $\begin{array}{l}\mathrm{PP} \\
\mathrm{N} 4\end{array}$ & $\begin{array}{l}4 \mathrm{PN} \\
1\end{array}$ & $\begin{array}{l}4 \mathrm{P} \\
\mathrm{N} 2\end{array}$ & $\begin{array}{l}\mathrm{P} \\
\mathrm{N} 3\end{array}$ & $\begin{array}{l}4 \mathrm{PNN} \\
4\end{array}$ \\
\hline Lepidoptera & Pyralidae & $\begin{array}{l}\text { C.medi } \\
\text { nalis }\end{array}$ & + & + & + & + & + & + & + & + & + & + & + & + & + & + & + & + \\
\hline Lepidoptera & Hesperiidae & $\begin{array}{l}\text { Pelopid } \\
\text { assp }\end{array}$ & + & + & + & + & + & + & + & + & + & + & + & + & + & + & + & + \\
\hline Lepidoptera & Crambidae & $\begin{array}{l}\text { S.incert } \\
\text { ulas }\end{array}$ & ++ & ++ & +++ & ++ & ++ & ++ & ++ & ++ & ++ & ++ & ++ & ++ & ++ & ++ & ++ & ++ \\
\hline Lepidoptera & Crambidae & $\begin{array}{l}\text { S.inona } \\
\text { ta }\end{array}$ & ++ & ++ & ++ & ++ & ++ & ++ & ++ & ++ & +++ & +++ & + & $\begin{array}{l}++ \\
+\end{array}$ & +++ & +++ & + & ++ \\
\hline Lepidoptera & Nymphalidae & M.leda & + & + & + & + & + & + & + & + & + & + & + & + & + & + & + & + \\
\hline Lepidoptera & Pyralidae & $\begin{array}{l}\text { Chilo } \\
\text { supress } \\
\text { alis }\end{array}$ & + & + & + & + & + & + & + & + & + & + & + & + & + & + & + & + \\
\hline Lepidoptera & Pyralidae & $\begin{array}{l}\text { S. } \\
\text { furciper } \\
a\end{array}$ & ++ & ++ & ++ & ++ & ++ & ++ & ++ & ++ & +++ & +++ & ++ & ++ & +++ & +++ & +++ & ++ \\
\hline $\begin{array}{l}\text { Mesogastro } \\
\text { poda }\end{array}$ & Ampullaridae & $\begin{array}{l}\text { Pomace } \\
\text { a sp }\end{array}$ & ++ & ++ & ++ & ++ & ++ & ++ & ++ & ++ & ++ & ++ & ++ & ++ & ++ & ++ & ++ & ++ \\
\hline Odonata & Coenagrionidae & $\begin{array}{l}\text { A.femin } \\
a\end{array}$ & ++ & ++ & ++ & ++ & $\overline{+++}$ & ++++ & ++ & +++ & ++ & ++ & ++ & ++ & +++ & +++ & +++ & +++ \\
\hline Odonata & Coenagronidae & $\begin{array}{l}\text { A.pygm } \\
\text { aea }\end{array}$ & +++ & ++ & +++ & ++ & ++ & ++ & ++ & ++ & ++ & ++ & +++ & ++ & ++ & ++ & +++ & ++ \\
\hline Odonata & Coenagrionidae & $\begin{array}{l}\text { I.seneg } \\
\text { alensis }\end{array}$ & + & + & + & + & + & + & + & + & + & + & + & + & + & + & + & + \\
\hline Odonata & Coenagrionidae & $\begin{array}{l}\text { P.rubic } \\
\text { eps }\end{array}$ & + & + & + & + & + & + & + & + & + & + & + & + & + & + & + & + \\
\hline Odonata & Libellullidae & $\begin{array}{l}\text { C.servil } \\
\text { lia }\end{array}$ & + & + & + & + & + & + & + & + & + & + & + & + & + & + & + & + \\
\hline Odonata & Libellullidae & $\begin{array}{l}\text { O.sabin } \\
a\end{array}$ & ++ & ++ & ++ & ++ & ++ & ++ & ++ & ++ & +++ & +++ & ++ & $\begin{array}{l}++ \\
+ \\
\end{array}$ & +++ & +++ & ++ & ++ \\
\hline Odonata & Libellullidae & $\begin{array}{l}\text { P.flaves } \\
\text { cen }\end{array}$ & ++ & ++ & ++ & ++ & ++ & ++ & ++ & ++ & ++ & ++ & ++ & ++ & ++ & ++ & ++ & ++ \\
\hline Odonata & Libellulidae & $\begin{array}{l}\text { T.auror } \\
a\end{array}$ & + & + & + & + & + & + & + & + & + & + & + & + & + & + & + & + \\
\hline Odonata & Libellullidae & $\begin{array}{l}\text { T.tillar } \\
\text { ga }\end{array}$ & + & + & + & + & + & + & + & + & + & + & + & + & + & + & + & + \\
\hline Orthoptera & Tetrigidae & A.lata & + & + & + & + & + & + & + & + & + & + & + & + & + & + & + & + \\
\hline Orthoptera & Gyrllidae & $\begin{array}{l}\text { Gryllus } \\
\mathrm{sp}\end{array}$ & + & + & + & + & + & + & + & + & + & + & + & + & + & + & + & + \\
\hline Orthoptera & Tetrigidae & $\begin{array}{l}\text { Melano } \\
\text { pledes } \\
\mathrm{sp}\end{array}$ & + & + & + & + & + & + & + & + & + & + & + & + & + & + & + & + \\
\hline
\end{tabular}

Catatan: Angka pertama 1,2,3,4 menunjukkan waktu pengambilan sampel 1,2,3,4; manakala PN1 = Pestisida Nabati 1; PN2 = Pestisida nabati 2; PN3 = Pestisida nabati 3; PN4 = Pestisida nabati 4. Selanjutnya $+=1-10$ ekor, $++=11-20$ ekor, $+++=21-30$ ekor. 
Data penelitian ini didukung oleh Ikhsan dkk (2018) mengidentifikasi sebanyak 8 Ordo padi pasang surut di Kabupaten Indragiri Hilir. Manakala Siregar dkk (2014) mencatat lebih sedikit, yaitu 6 Ordo dan 16 Famili hama-hama padi di lahan pada Kampung Susuk, Medan. Ordo dengan populasi tertinggi dari penelitian ini diidentifikasi pada lahan padi merah Natabo dengan aplikasi pestisida nabati, yaitu Ordo Hemiptera dengan total 236 ekor, diikuti Ordo
Lepidoptera sebanyak 209 ekor, Ordo Diptera dengan jumlah 165 ekor, Hymenoptera sebesar 146 ekor dan Ordo Coleoptera teridentifikasi sebanyak 125 ekor pada lahan padi menggunakan pestisida nabati. Manakala Ordo Hemiptera teridentifkasi sebanyak 248 ekor, diikuti Ordo Hymenoptera sebesar 213 ekor, lalu Ordo Lepidoptera sebanyak 219 ekor, Ordo Diptera berjumlah 167 ekor, dan Ordo Coleoptera sebesar 135 ekor (Gambar 1).

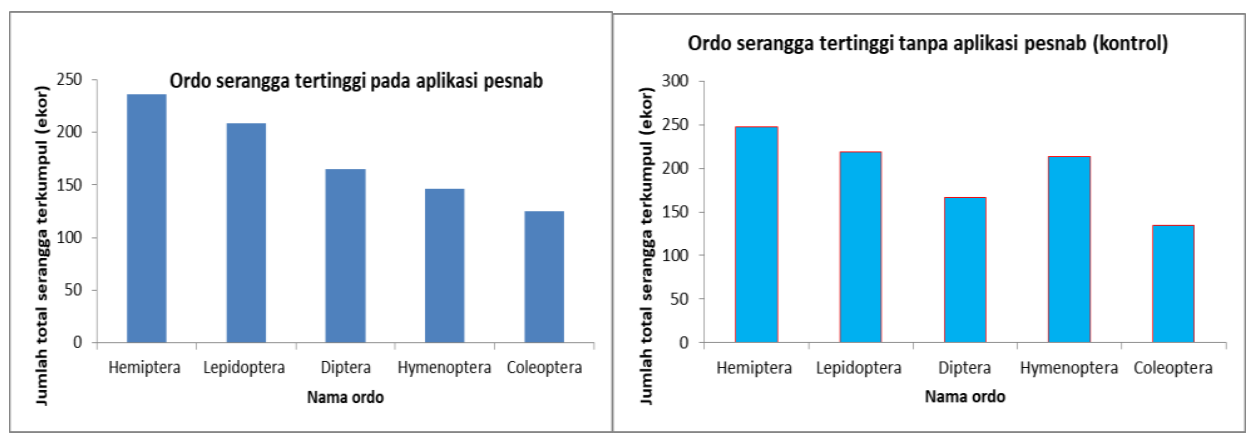

Gambar 1. Jumlah Ordo teridentifikasi pada aplikasi pesnab dan lahan pada tanpa pesnab (kontrol)

Terdapat 3 famili dengan populasi terbesar dari kedua lahan padi, yaitu Alydidae, Chrysomelidae, Delphacidae, Crambidae dan Pyralidae. Kelima famili yang diidentifikasi terbesar pada pertanaman padi merah, didukung penelitian yang dilakukan Ane \& Hussain (2016) dari jenis Scirpophaga incertulas, $S$. innotata, Chilo suppressalis, $C$. polychrysus, dan Sesamia inferens mendominasi padi. Manakala Suprapto \& Hafif (2012) serta Tangkilisan et al. (2013) mencatat populasi Cnaphalocrosis medinalis terbesardi padi, disamping jenis Nephotettix virescens (Widiarta et al., 2014), Nilaparvata lugens (Baehaki, 2011; Prayana et al., 2013), Leptocorisa spp., dan Scotinophara coarctata (Sepe \& Demayo,2014) masih menjadi hamahama utama yang diidentifikasi di lahan padi.
Selanjutnya Tarigan (2019) menyatakan populasi serangga yang paling fluktuatif dilihat dari jenis serta jumlahnya saat penangkapan pertama hingga ke empat disebabkan pertanaman sedang memasuki fase vegetatif sehingga serangga mempunyai makanan yang berlimpah, predator belum bekerja secara maksimal karena mangsanya belum berlimpah serta persaingan antara serangga masih rendah. Dan hal ini terbukti dari data serangga yang dikumpulkan pada pengambilan sampel minggu ketiga dan keempat menujukkan jumlah yang lebih besar dibandingkan pengumpulan serangga di minggu pertama dan minggu kedua penyampelan dengan aplikasi pestisida nabati dilahan padi merah.

Disamping itu, jumlah serangga berbeda jauh antara penggunaan pestisida nabati dan lahan kontrol, diduga 
kandungan kimia dari penggunaan pestisida nabati variasi dari daun dan bunga kenikir (Cosmos caudatus), marigold (Tagetes erecta), dan bunga kertas (Zinnia peruviana) mempengaruhi keberadaan serangga pada lahan padi.Daun kenikir mengandung saponin, flavonoid polifenol dan minyak atsiri. Akarnya mengandung hidroksiegenol dan koniferil alkohol. Kenikir dapat berfungsi sebagai penambah nafsu makan, lemah lambung, penguat tulang dan pengusir serangga (Rahayu dkk., 2012), manakala daun marigold dapat berperan sebagai anti repelan pada nyamuk (Sakthivadivel et al., 2016; Marini, dkk., 2018) dan daun bunga kertas dapat mengontrol aktivitas WBC (N.lugens) dan walang sangit ( $L$. acuta) pada padi (Hidayah, 2019).

\section{Perhitungan Indek Biologi}

Selanjutnya dilakukan perhitungan biologi, terdiri dari indek kekayaan jenis (Richness Index Margalef), Indek Keseragaman (Evennes Index) dan Indeks Keanekaragaman (Shannon Wiener Index) dengan masing-masing nilai sebagaimana terlihat oada Tabel 2 dibawah ini.

Tabel 2. Perhitungan nilai indek biologi pada lahan aplikasi pesnab dan lahan tanpa pesnab

\begin{tabular}{ccc}
\hline Pengamatan & Lahan dengan pesnab & Lahan tanpa pesnab \\
\hline $\mathrm{R}$ & 7,25 & 7.15 \\
\hline $\mathrm{E}$ & 0.62 & 0.57 \\
\hline $\mathrm{H}^{\prime}$ & 2.38 & 2.12 \\
\hline
\end{tabular}

Dimana pada lahan padi merah dengan Pesnab memiliki nilai kekayaan jenis sebesar 7,25 dan pada lahan tanpa Pesnab sebesar 7.15. Nilai kekayaan jenis kedua lahan ini termasuk dalam kategori yang tinggi karena lebih dari 4. Nilai kekayaan jenis ini digunakan untuk mengetahui kekayaan jenis serangga dalam setiap komunitasnya. Hal ini didukung pendapat Siregar (2020), indeks kekayaan jenis berfungsi untuk mengetahui kekayaan jenis setiap spesies dalam setiap komunitasnya yang dijumpai.

$$
\text { Selanjutnya, Peet }
$$

menyatakan bahwa kriteria kekayaan jenis Margalef terbagi 3 dimana $\mathrm{R}<2,5$ menunjukkan kekayaan jenis yang rendah, 2,5>R>4 menunjukkan kekayaan jenis yang sedang dan $\mathrm{R}>4$ menunjukkan kekayaan jenis yang tinggi. Jika dibandingkan dengan penelitian Adawiyah et al. (2020) pada lahan dengan Pesnab Zinnia acceeraso memiliki nilai kekayaan jenis sebesar 1,077 yang masuk dalam kategori kekayaan jenis yang rendah. Perbedaan nilai kekayaan jenis yang sangat signifikan ini dikarenakan perbedaan tanaman utama yaitu tomat sedangkan peneliti menggunakan padi merah dan penggunaan jumlah jenis tanaman pesnab pada satu lahan, dimana pada lahan padi merah menggunakan 3 jenis Pesnab yaitu kenikir (Cosmos caudatus), marigold (Tagetes erecta), bunga kertas (Zinnia elegans).

Dari penelitian yang telah dilakukan, diketahui nilai indeks kemerataan lahan (Evenness Index) pada lahan padi merah dengan pesnab $(\mathrm{E}=0.62)$ dan tanpa pesnab $(\mathrm{E}=0.57)$ tidak begitu berbeda, termasuk dalam kategori sedang. Hal ini sesuai dengan Odum (1996) yang menyatakan kriteria indeks kemerataan jenis terbagi 3 yaitu, $E^{\prime}<0,3$ menunjukkan kemerataan jenis yang termasuk dalam kategori rendah, $0,3>E^{\prime}>0,6$ menunjukkan kemerataan jenis yang termasuk dalam kategori sedang dan E' $>0,6$ menunjukkan kategori tinggi dimana maksimal indeks 
kemerataan jenis ini adalah 1. Didukung pendapat Oka (1995), nilai kemerataan akan tinggi apabila jumlah dari populasi dalam suatu famili tidak mendominasi famili lainnya sedangkan kemerataan akan bernilai rendah apabila terdapat suatu famili yang memiliki jumlah yang mendominasi dari total keseluruhan populasi yang ada.

Hasil penghitungan indeks keanekaragam H' sebesar 2.12-2.38 menunjukkan kategori keanekaragaman serangga sedang pada padi merah di Soporaru. Michael (1995) menyatakan jika $H^{\prime}=1-3$ menunjukkan keanekaragaman serangga yang sedang yaitu keberadaan hama dan musuh alami hampir menunjukkan keseimbangan. Indeks keanekaragaman merupakan deskripsi matematik yang mempermudah peneliti dalam menganalisis informasi mengenai jumlah jenis individu serta berapa banyak jumlah jenis individu tersebut dalam suatu area.

Nilai indeks keanekaragaman lahan padi merah dengan 4 jenis pesnab sebesar $\mathrm{H}^{\prime}=2,38$ menunjukkan angka yang lebih tinggi dibandingkan indeks keanekaragaman pada penelitian Tarigan pada padi merah di Karo sebesar $\mathrm{H}^{\prime}=2.53$ menggunakan 4 refugia ( $T$. erecta, Impatiens balsamina, C. caudatus dan $Z$. peruviana), lebih rendah pada penelitian Qomariyah (2017) di Desa Sumberngepoh, Kec. Lawang Kabupaten Malang sebesar 2.04, menggunakan satu jenis bunga kenikir (Cosmos sulphureus).

\section{Faktor Lingkungan}

Faktor-faktor lingkungan yang diukur, diantaranya adalah suhu, kelembaban, dan curah hujan sebagaimana dideskripsikan pada Tabel 3 dibawah ini.

Tabel 3. Pegukuran suhu, kelembaban, curah hujan

\begin{tabular}{cccc}
\hline Pengamatan & Suhu $\left({ }^{\circ} \mathbf{C}\right)$ & Kelembaban $(\boldsymbol{\%})$ & Curah hujan (\%) \\
\hline I & 30 & 93 & 186 \\
II & 33 & 95 & 198 \\
III & 32 & 94 & 223 \\
IV & 31 & 91 & 245 \\
\hline
\end{tabular}

Dari penelitian yang telah dilakukan, diperoleh penurunan populasi serangga tertangkap pada penyampelan keempat dimana data suhu $31^{\circ} \mathrm{C}$ dengan kelembaban $91 \%$ dan curah hujan $245 \%$. Hal ini berkaitan juga dengan hari hujan dimana pada pengamatan ke-4 terjadi hujan sehingga pengurangan populasi serangga tertangkap yang sangat signifikan. Wardani (2017) berpendapat hujan secara langsung dapat mempengaruhi populasi serangga hama apabila hujan besar serangga hama banyak yang mati, berpengaruh terutama pada pertumbuhan dan keaktifan serangga. Pengaruh hujan pada kehidupan serangga bisa bersifat lansung secara mekanik atau secara tidak langsung terhadap keadaan udara dan tanah. Selanjutnya, Sulistyani dan Rahayuningsih (2013) menyatakan intensitas cahaya merupakan faktor lingkungan yang mempengaruhi peningkatan suhu dimana hal ini berkaitan dengan peningkatan kemampuan melihat, perkembangan larva, mempengaruhi aktivitas terbang, aktivitas pakan, dan reproduksi serangga. Pada Suhu optimum, kemampuan hama 
untuk melahirkan keturunan amat besar dan kematian (mortalitas) yang sedikit.

Hasil produksi padi merah Natabo menggunakan pesnab sebanyak $960 \mathrm{~kg}$, manakala lahan tanpa pesnab menghasilkan produksi beras merah sebesar $875 \mathrm{~kg}$. Didukung penelitian Sakir dan Desinta (2018) terjadi peningkatan sebesar $15,1 \% / \mathrm{Ha}$ pada lahan padi yang menggunakan refugia dan pesnab dimana produksi padi ratarata sebesar 8,1 ton per hektar. Dimana sebelumnya saat padi masih menggunakan insektisida untuk membasmi hama padi, produksi padi pada tahun tersebut dengan menggunakan varietas Ciherang dan IR 42 diperoleh hasil 5,4 ton/Ha. Penggunaan pesnab menunjukkan dampak populasi musuh alami yang meningkat yaitu berupa predator, parasitoid dan polinator yang akan mengkonsumsi hama-hama utama padi. Keberadaan beragam musuh alami sebagai salah satu komponen ekosistem pertanian dapat mempertahankan komponen rantai makanan sehingga terjadinya kestabilan agroekosistem pada lahan suboptimal.

\section{KESIMPULAN}

Aktivitas hama penggerek batang, wereng batang coklat, wereng daun, walang sangit yang teridentifikasi pada beras merah spesifik lokal Natabo di Kecamatan Pangaribuan, Tapanuli Utara. Pengendalian Hayati menggunakan pestisida nabati (pesnab) merupakan salah satu cara untuk meningkatkan produktivitas dan ketahanan pangan. Aplikasi pestisida nabati terdiri dari 5 perlakuan, yaitu: B0 (Kontrol, tanpa aplikasi); BP1 (daun nimba, lengkuas, serai, deterjen, air); BP2 (daun sirsak, rimpang jeringau, bawang putih, deterjen, air); BP3 (daun sirsak, deterjen, air) dan BP4 (daun kenikir, bunga marigold, daun-bunga kertas). Komposisi serangga menggunakan aplikasi pesnab terdiri dari 8 ordo, 26 famili dengan total sebanyak 1.080 ekor, sedangkan lahan tanpa aplikasi pestisida nabati terdiri dari 9 ordo, 30 famili dengan total populasi sebanyak 1349 ekor. Perhitungan indeks kekayaan jenis (R) Margalef $(\mathrm{R} p=7.25$; $\mathrm{Rk}=7.15)$, indeks kemerataan Evenness $(\mathrm{Ep}=0.62 ; \quad \mathrm{Ek}=0.57) \quad$ serta indeks keanekaragaman Shannon Wiener $\left(\mathrm{Hp}^{\prime}=2.38 ; \quad \mathrm{Hk}=2.12\right) . \quad$ Perhitungan parameter suhu, kelembaban, curah hujan) dihitung. Diprediksikan pemanfaatan pestisida nabati berpotensi strategis dalam mengendalikan hama dominan padi di masa depan.

\section{UCAPAN TERIMA KASIH}

Terima kasih disampaikan kepada REktor Universitas Sumatera Utara dan LPPM USU yang telah memberikan Hibah Penelitian Talenta USU dengan skema Penelitian Dasar dengan Nomor Kontrak 38/UN5.2.3.1/PPM/SPPTALENTA USU/ 2020. Ucapakan terima kasih yang tulus disampaikan kepada petani dan masyarakat Soporaru serta mahasiswa saya Rohyanti Nabanan dan Sampe Hasibuan yang telah membantu terlaksana penelitian ini.

\section{DAFTAR PUSTAKA}

Adawiyah, R., Aphrodyanti, L., Aidawati, N. (2020). Pengaruh Warna Bunga Refugia Terhadap Keanekaragaman Serangga Pada Pertanaman Tomat (Solanum lycopersicum). JURNAL PROTESKI TANAMAN TROPIKA 3 (1), 194-199.

Aldini, G.M., Martono, E., Trisyono, Y.A. (2019). Diversity of Natural Enemies Associated with Refuge Flowering Plants of Zinnia elegans, Cosmos sulphureus, and Tagetes erecta in Rice Ecosystem. JURNAL 
PERLINDUNGAN TANAMAN INDONESIA 23(2), 285-291.

Amiranti, P. (2005). Studi Pengaruh Ekstrak Bawang Putih (Allium sativum L.) Terhadap Perkembagan Pra Dewasa nyamuk Culex pipiens q. Skripsi (tidak dipublikasikan) Fakultas Kedokteran Hewan.Institut Pertanian Bogor. Bogor.

Ane, N.I.U. and Hussain, M. (2016). Diversity of insect pests in major rice growing of the world. JOURNAL OF ENTOMOLOGY AND ZOOLOGY STUDIES 4(1), 36-41.

Badan Pusat Statistik. (2020). Produksi, Luas Panen, dan Produktivitas Padi Indonesia. Badan Pusat Statistik, Jakarta.

Baehaki, S.E. (2011). Strategi fundamental pengendalian hama wereng batang coklat dalam pengamanan produksi padi nasional. JURNAL PENGEMBANGAN INOVASI PERTANIAN 4(1), 63-75.

Jayati, R.D., Lestari, F, Betharia,R. (2018). Pengaruh Pestisida Nabati Ekstrak Daun Kenikir (Cosmos caudatus) terhadap Mortalitas Ulat Grayak (Spodoptera litura) pada Daun Bawang (Allium fistulosum). JURNAL BIOEDUSAINS: JURNAL PENDIDIKAN BIOLOGI DAN SAINS 3 (1), 6674.

Henny, Makal and Turang, D. (2011). Pemanfaatan Ekstrak Kasar Batang Serai dan Lengkuas Untuk Pengendalian Larva Crosidolomia binotalis Zell Pada Tanaman Kubis. Universitas Sam Ratulangi,Manado.
Hidayah, N. (2019). Pengaruh Kepadatan Bunga Kertas (Zinnia sp) Sebagai Refugia Terhadap Densitas Wereng (Nilaparvata lugens Stal.) dan Walang Sangit (Leptocorisa acuta Thumb.) di Lahan Padi Desa Tambakrejo (Pemanfaatannya Sebagai Buku Ilmiah Populer). Skripsi S1 Universitas Jember, Jawa Timur.

Ihsan, Z, Hidrayani, Yaherwandi, Hasmiandy,H. (2018). Inventarisasi serangga pertanaman padi pasang surut pada saat sebelum tanam di Kabupaten Indragiri Hilir, Riau. JURNAL SELODANG MAYANG 4 (1), 51-59.

Kardinan, A. (1999). Pestisida Nabati, Ramuan dan Aplikasi. Penebar Swadaya, Jakarta.

Kardinan, A. 2004.Pengaruh minyak biji mimba (Azadirachta indica) sebagai daya penolak makan dan insektisida pada serangga Dolleschalia pollibete. JURNAL ILMIAH PERTANIAN GAKURYOKU 10 (2), 153-156.

Kardinan, A. (2005). Penggunaan atraktan nabati untuk mengendalikan hama lalat buah dalam sistem pertanian organik. hlm.145-155. Prosiding Workshop Masyarakat Pertanian Organik Indonesia.

Kardinan, A. (2006). Bioekologi dan strategi pengendalian lalat buah.hlm. 49-59. Prosiding Seminar Nasional dan Pameran Pestisida Nabati III.Balai Penelitian Tanaman Rempah dan Obat, Bogor. 
Kardinan, A. (2007). Potensi selasih sebagairepellent terhadap nyamuk Aedes aegypti. JURNAL PENELITIAN TANAMAN INDUSTRI 13(2), 39-42.

Listiyati, A.K., Nurkalis, U., Sudiyanti, dan Hestiningsih, R. (2012). Ekstraksi nikotin dari daun tembakau (Nicotina tabacum) dan pemanfaatannya sebagai insektisida nabati pembunuh Aedes sp. JURNAL ILMIAH MAHASISWA 2 (2), 67-70.

Marini, Ni'mah, T, Mahdalena, V, Komariah R.H,, Sitorus, H. (2018). Potensi Daya Tolak Ekstrak Daun Marigold (Tegetes erecta) terhadap Nyamuk Aedes aegypti. JURNAL BALABA 14(1), 15-19.

Michael. 1985. Ecological Methods. Wiley and Sons, UK. 98p.

Muhibah, T.I. dan Leksono, L. (2015). Attraction of arthropods in refugia blocks (Ageratum conyzoides L., Capsicum frustecens L., and Tagetes erecta L.) with the application of liquid organic fertilizer and biopesticide in apple crops in Poncokusumo. JOURNAL OF TROPICAL BIOLOGI BIOTROPIKA 3 (3), 123-127.

Odum, H.T. (1996). Scale of Ecological Engeenering. Ecological Enggenering 6: 7-19.

Oka, I.N., (2005). Pengendalian Hama Terpadu dan Implementasinya di Indonesia. Gadjah Mada University Press, Yogyakarta.
Putra, S dan Zein, S. (2016). Pengaruh variasi konsentrasi ekstrak serai (andropogon nardus) terhadap mortalitas hama keong mas (Pomacea caniculata L.). JURNAL PENDIDIKAN BIOLOGI BIOEDUKASI 7 (1), 10-15.

Peet, R.K. (1975). Relative Diversity Ecology. Wiley Online Library, USA.

Prayana, N.A., Mudjiono, G. and Rahardjo, B.T. (2013). Population management strategy implementation brown planthopper Nilaparvata lugens Stal. (Homoptera: Delphacidae) integrated. INTERNATIONAL JOURNAL OF SCIENCE AND RESEARCH 2 (12), 389-394.

Qomariyah, L. (2017). Efek tanaman Kenikir (Cosmos Sulphureus) sebagai refugia terhadap keanekaragaman serangga Aerial di Sawah Padi Organik Desa Sumberngepoh Kecamatan Lawang Kabupaten Malang. Skripsi S1, Universitas Islam Negeri Maulana Malik Ibrahim, Jawa Timur.

Rahayu,M., Pakki. T, Saputri,. R. (2012). Uji Konsentrasi Cairan Perasan Daun Kenikir (Tagetes patulaJuss) terhadap Mortalitas Ulat Penggulung Daun (lamprosema indica ) pada Tanaman Ubi Jalar. Fakultas Pertanian Universitas Haluoleo, Kendari. JURNAL AGROTEKNOS 2(1), 36-40. 
Rusdy, A. (2010). Pengaruh Pemberian Ekstrak Bawang Putih Terhadap Mortalitas Keong Mas. JURNAL FLORATEK 5, 172-180.

Sakir, I.M., Desinta. (2018). Pemanfaatan Refugia Dalam Meningkatkan Produksi Tanaman Padi Berbasis Kearifan Lokal. JURNAL LAHAN SUBOPTIMAL 7 (1), 97-105.

Sakthivadive, M., Gunasekaran, P, Tenzin, G. (2016). Laboratory evaluation of Asteraceae species Tagetes erecta Linnaeus and Tridax procumbens Linnaeus for their toxicity against the larvae of Say 1823 (Culex quinquefasciatu: Diptera, Culicidae). JOURNAL OF MOSQUITO 3(3), 35-46.

Sepe, M.C. and Demayo, C.G. (2014). Quantitative description of head shape dimorphism in the rice black bug Scotinophara sp. using landmarkbased geometric morphometric analysis. JOURNAL OF APPLIED SCIENCE AND AGRICULTURE 9 (11), 263-270.

Siregar, A.Z. (2018). Karakteristik Hama Padi Pasang Surut.Intimedia, 122hlm.

Siregar, A.Z., Rahmi, Sitepu, S. F. (2020). Keanekaragaman Serangga Di Pertanaman Kecombrang (Etlingera Elatior Jack) Pada Zona Penyangga Kawasan Taman Nasional Gunung Leuser. JURNAL ILMU PERTANIAN DAN KEHUTANAN AGRIFOR 19 (2), 191-200.

Siregar, A.Z., Tulus, Lubis, K.,S. 2017. Pemanfaatan Tanaman Atraktan Mengendalikan Hama Keong Mas Padi. JURNAL AGROSAINS DAN TEKNOLOGI 2(2), 121-134.
Siregar, A.,S, Bakti, D, Zahara, F. 2014. Keanekaragaman Jenis Serangga Di Berbagai Tipe Lahan Sawah. JURNAL AGROTEKNOLOGI USU 2 (4), 1640-1647.

Sulistyani, Rahayuningsih, M, Prataya. (2013). Keanekaragaman Jenis Kupu-Kupu (Lepidoptera: Rhopalocera) Di Cagar Alam Ulolanang Kecubung, Kabupaten Batang. JURNAL OF BIOLOGY LIFE SCIENCE 3 (1), 47-56.

Suprapto and Hafif, B. (2012). Serangan hama putih palsu (Cnaphalocrocis medinalis Gunee) dan penampilan agronomik pada beberapa varietas padi. JURNAL PENELITIAN PERTANIAN TERAPAN 12(1), 3642.

Sodiq, M. dan Mudjoko, T. (2019). Pengendalian Terpadu Hama dan Penyakit Tanaman Padi. Plantaxia, Graha Ilmu. 120hlm.

Tangkilisan, V.E., Salaki, C.L., Dien, M.F., \& Meray, E.R.M. (2013). Serangan hama putih palsu Cnaphalocrosis medinalis Guenee. pada tanaman padi sawah di Kecamatan Ranoyapo, Kabupaten Minahasa Selatan. JURNAL EUGENIA 19(3), 23-29.

Wardhani, D, Wulan, S.,R. (2017). Korelasi Curah Hujan dan Tata Guna Lahan Terhadap Kejadian Malaria di Kota Bandar Lampung. JURNAL AGROMEDICINE 4 (2), 18-23. 
Widiarta, I.N., Bastian, A., and Pakki, S. (2014). Variation in rice tungro virus transmission ability by green leafhopper, Nephotettix virescens Distant (Homoptera: Cicadellidae) on rice resistant varieties. INDONESIAN JOURNAL OF AGRICULTURAL SCIENCE 15(2), 65-70.
Wiyono, S., Widodo,Triwidodo, H. (2014). Mengelola Ledakan Hama dan Penyakit Padi Sawah pada Agroekosistem yang Fragil dengan Pengendalian Hama Terpadu Biointensif. RISALAH KEBIJAKAN PERTANIAN DAN LINGKUNGAN 1 (2), 116-120. 